\title{
Incidental enchondromas at knee magnetic resonance imaging: intraobserver and interobserver agreement and prevalence of imaging findings*
}

Encondromas incidentais nos exames de ressonância magnética do joelho: concordância intraobservador e interobservador e prevalência das características de imagem

\author{
Sandra Akemi Nakamura ${ }^{1}$, Mário Müller Lorenzato ${ }^{2}$, Edgard Eduard Engel ${ }^{3}$, Maurício Eiji de Almeida \\ Santos Yamashita ${ }^{4}$, Marcello Henrique Nogueira-Barbosa ${ }^{5}$
}

\begin{abstract}
Objective: To evaluate intra- and interobserver agreement in the identification of incidental enchondromas at knee magnetic resonance imaging, and to assess the prevalence of imaging findings. Materials and Methods: Retrospective study reviewing 326 knee magnetic resonance images acquired in the period between November 2009 and September 2010. The images were independently and blindly analyzed by two specialists in musculoskeletal radiology, with the objective of identifying incidental enchondromas, presence of foci with signal similar to bone marrow and foci of signal absence suggestive of calcifications within the enchondromas. Inter- and intraobserver agreements were analyzed. Results: Eleven lesions compatible with enchondromas (3.3\%) were identified. The interobserver agreement for the presence of enchondroma was high. Prevalence of foci of bone marrow signal inside the enchondromas was of $54.55 \%$, and foci suggestive of calcification corresponded to $36.36 \%$. The intraobserver agreement for foci of bone marrow signal in enchondromas was perfect, and interobserver agreement was high. Conclusion: The prevalence of incidental enchondromas in the current study was compatible with data in the literature. Excellent agreement was observed in the identification of enchondromas and in the assessment of imaging findings. A higher prevalence of fat signal foci was observed as compared with signal absence suggestive of calcifications.
\end{abstract}

Keywords: Enchondromas; Magnetic resonance imaging; Knee; Bone marrow.

Resumo Objetivo: Avaliar a confiabilidade intra e interobservador na identificação de encondromas incidentais na ressonância magnética de joelho e estudar a prevalência das características de imagens destas lesões. Materiais e Métodos: Estudo retrospectivo, com revisão de 326 ressonâncias magnéticas do joelho realizadas entre novembro de 2009 e setembro de 2010. As imagens foram analisadas por dois médicos especialistas em radiologia musculoesquelética, de forma independente e às cegas, visando a identificar encondromas incidentais, presença de focos com sinal semelhante à medula óssea e focos de ausência de sinal sugestivos de calcificações no interior dos encondromas. Foram realizadas análises das concordâncias inter e intraobservador. Resultados: Foram identificadas 11 lesões compatíveis com encondromas (3,3\%). A concordância interobservador para presença de encondroma foi alta. A prevalência de focos de sinal de medula óssea no interior dos encondromas foi $54,55 \%$ e de focos sugestivos de calcificação foi $36,36 \%$. A concordância intraobservador para focos de sinal de medula óssea nos encondromas foi perfeita, e a concordância interobservador foi alta. Conclusão: A prevalência de encondromas incidentais no trabalho atual foi consistente com a literatura. Foi observada excelente concordância no estudo de confiabilidade da identificação de encondromas e de suas características, notando-se maior prevalência de focos com sinal de gordura do que de calcificações.

Unitermos: Encondromas; Ressonância magnética; Joelho; Medula óssea.

Nakamura SA, Lorenzato MM, Engel EE, Yamashita MEAS, Nogueira-Barbosa MH. Incidental enchondromas at knee magnetic resonance imaging: intraobserver and interobserver agreement and prevalence of imaging findings. Radiol Bras. 2013 Mai/Jun;46(3):129-133.

* Study developed at Hospital das Clínicas da Faculdade de Medicina de Ribeirão Preto da Universidade de São Paulo (HCFMRPUSP), Ribeirão Preto, SP, Brazil.

1. MD, Radiologist, Fellow of Musculoskeletal Radiology, Hospital das Clínicas da Faculdade de Medicina de Ribeirão Preto da Universidade de São Paulo (HC-FMRPUSP), Ribeirão Preto, SP, Brazil.

2. MD, Radiologist specialized in Musculoskeletal Radiology, Assistant, Division of Radiology, Center of Imaging Sciences and Medical Physics, Faculdade de Medicina de Ribeirão Preto da Universidade de São Paulo (FMRPUSP), Ribeirão Preto, SP, Brazil.

3. PhD, Professor, Department of Biomechanics, Medicine and Locomotor System Rehabilitation, Faculdade de Medicina de Ribeirão Preto da Universidade de São Paulo (FMRPUSP), Ribeirão Preto, SP, Brazil.

4. Assistant Physician, Senvice of Pathology, Hospital das Clínicas da Faculdade de Medicina de Ribeirão Preto da Universidade de São Paulo (HC-FMRPUSP), Ribeirão Preto, SP, Brazil.

5. PhD, Professor, Center of Imaging Sciences and Medica Physics, Faculdade de Medicina de Ribeirão Preto da Universidade de São Paulo (FMRPUSP), Ribeirão Preto, SP, Brazil.

Mailing Address: Dra. Sandra Akemi Nakamura. Av. Bandeirantes, 3900, Campus Universitário. Ribeirão Preto, SP, Brazil, 14048-900. E-mail: sandra_akemi_nakamura@yahoo.com.br.

Received October 19, 2012. Accepted after revision March 15, 2013.

\section{INTRODUCTION}

A range of recent studies published in Brazil have highlighted the relevance of imaging methods in the assessment of the musculoskeletal system ${ }^{(1-12)}$. In the present study, the authors evaluate the characteristics of enchondromas at knee magnetic resonance imaging (MRI). 
Enchondroma is a benign neoplasm of the intramedullary bone composed of hyaline cartilage. It is the second most common benign bone neoplasia just after osteochondroma. It is believed that enchondromas represent $12 \%$ to $24 \%$ of all benign bone tumors and $3 \%$ to $10 \%$ of all bone tumors $^{(13)}$.

In the study developed by Walden et al., 449 consecutive routine knee MRI studies were evaluated, and the authors observed the prevalence of incidental enchondromas in $2.9 \%$ of the images ${ }^{(\mathbf{1 3})}$. Such authors suggest that the recognition of incidental enchondromas is important to avoid confusion with other diseases.

The typical MRI finding of enchondroma is described as a lesion with lobulated contours, characterized by the presence of hypersignal on fluid-sensitive images, and with heterogeneous signal intensity on T1-weighted images ${ }^{(\mathbf{1 4})}$. The increased signal intensity of enchondromas on fluid-sensitive images is due to the great amount of fluid present in the hyaline cartilage that forms such lesions. However, the literature does not emphasize the characteristics of findings of enchondromas on T1weighted images.

The identification of foci of bone tissue or bone marrow within enchondromas is well documented on histopathological studies $^{(\mathbf{1 5}, \mathbf{1 6})}$. In a retrospective study, Murphey et al. found the presence of foci of hypersignal within lesions on T1weighted images of enchondromas and low-grade chondrosarcomas, and have correlated such MRI image with histopathological findings ${ }^{(\mathbf{1 7})}$.

The present study aimed at assessing the reproducibility of the identification of incidental enchondromas and evaluating the prevalence of such lesions as well as the prevalence of MRI findings of incidental enchondromas.

\section{MATERIALS AND METHODS}

The present retrospective study was approved by the Committee for Ethics in Research of Hospital das Clínicas da Faculdade de Medicina de Ribeirão Preto da Universidade de São Paulo, and reviewed consecutive knee MRI studies performed in the period from November 2009 to September
2010, regardless the clinical complaints and age of the patients. The images were independently and blindly analyzed by each one of two radiologists at two different moments with a three-month interval between the first and the second readings. One of the radiologists has ten-year experience in musculoskeletal radiology, and the other, two-year experience following a post-graduation in musculoskeletal radiology.

The MR images were acquired in a highfield $1.5 \mathrm{~T}$ equipment, with T1-weighted sequences (TR/TE, 500/20) in sagittal plane, and intermediate weighting sequences with fat suppression in axial/sagittal/coronal planes (TR/TE, 2000-3000/50).

The criteria adopted by the radiologists to diagnose an incidental enchondroma by MRI were the same used in the study developed by Walden et al. ${ }^{(\mathbf{1 3})}$. It were considered incidental enchondromas bone marrow focal changes that met the following criteria: focal geographic areas of bone marrow replacement on T1-weighted images, and with high signal intensity on fluid-sensitive images with fat suppression, and lobulated contours on both T1 and intermediate weightings. Focal alterations with the mentioned characteristics, but with subchondral location, were not classified as enchondromas, since they might correspond to subchondral cysts or intraosseous ganglion (mucous) cysts.

The two radiologists analyzed each image and recorded the respective findings of foci of signal similar to bone marrow signal or foci of signal suggesting the presence of calcifications within lesions classified as incidental enchondromas. The criterion utilized to characterize foci of bone marrow within incidental enchondromas was the presence of areas of hypersignal similar to bone marrow signal on T1-weighted images, with signal loss similar to the decrease in bone marrow signal on intermediate weighting images with fat suppression (Figure 1). The criterion utilized to characterize the presence of calcifications within the lesions corresponded to foci of signal absence on T1-weighted sequences and on intermediate weighting sequences with fat suppression (Figure 2).

The largest diameter of each focal alteration compatible with incidental enchon- droma was measured with a digital caliper on a workstation with the software Clear Canvas version 2.0.

Analyses were performed to evaluate the intra and interobserver agreement in the identification of incidental enchondromas and also foci of bone marrow and calcifications within the lesions at MRI. The statistical analysis was based on the kappa index $(\kappa)$. A coefficient $\kappa=1$ corresponds to a perfect agreement. A coefficient $\kappa$ equal to zero indicates a randomly expected agreement. Negative values occur in cases where the agreement is poorer than randomly expected but, according to Agresti ${ }^{(\mathbf{1 8})}$, this is rarely observed. Landis et al. ${ }^{(\mathbf{1 9})}$ provide the following classification for coefficient $\kappa$ : absent agreement $(\kappa<0)$, neglectable agreement $(0.00<\kappa<0.20)$, reasonable agreement $(0.21<\kappa<0.40)$, moderate agreement $(0.41<\kappa<0.60)$, substantial agreement $(0.61<\kappa<0.80)$, almost perfect agreement $(0.81<\kappa<1.00)$.

The authors have also evaluated the relationship between findings of foci of signal similar to bone marrow within the enchondromas and lesion size, sex and age of patients; and between presence of calcifications within the lesions and the already mentioned variables. For the variable sex, the Fisher's exact test was utilized to evaluate the association between two categorical variables; and for the variables lesion size and patient's age, the non-parametric Wilcoxon-Mann-Whitney test was utilized.

In the cases of disagreement in relation to the presence or not of areas of fat signal within the incidental enchondromas, further evaluation was performed by a third observer with 16-year experience in musculoskeletal radiology. Such a third evaluation allowed the calculation of the final prevalence of areas of bone marrow signal within the incidental enchondromas in the study sample.

\section{RESULTS}

On the 326 consecutive knee MRI studies, 11 lesions compatible with enchondromas were identified, resulting in a prevalence of $3 \%$ of incidental findings of enchondromas at routine knee MRI. Out of the whole study sample [male patients, $55.21 \%(n=180)$ and female patients, 


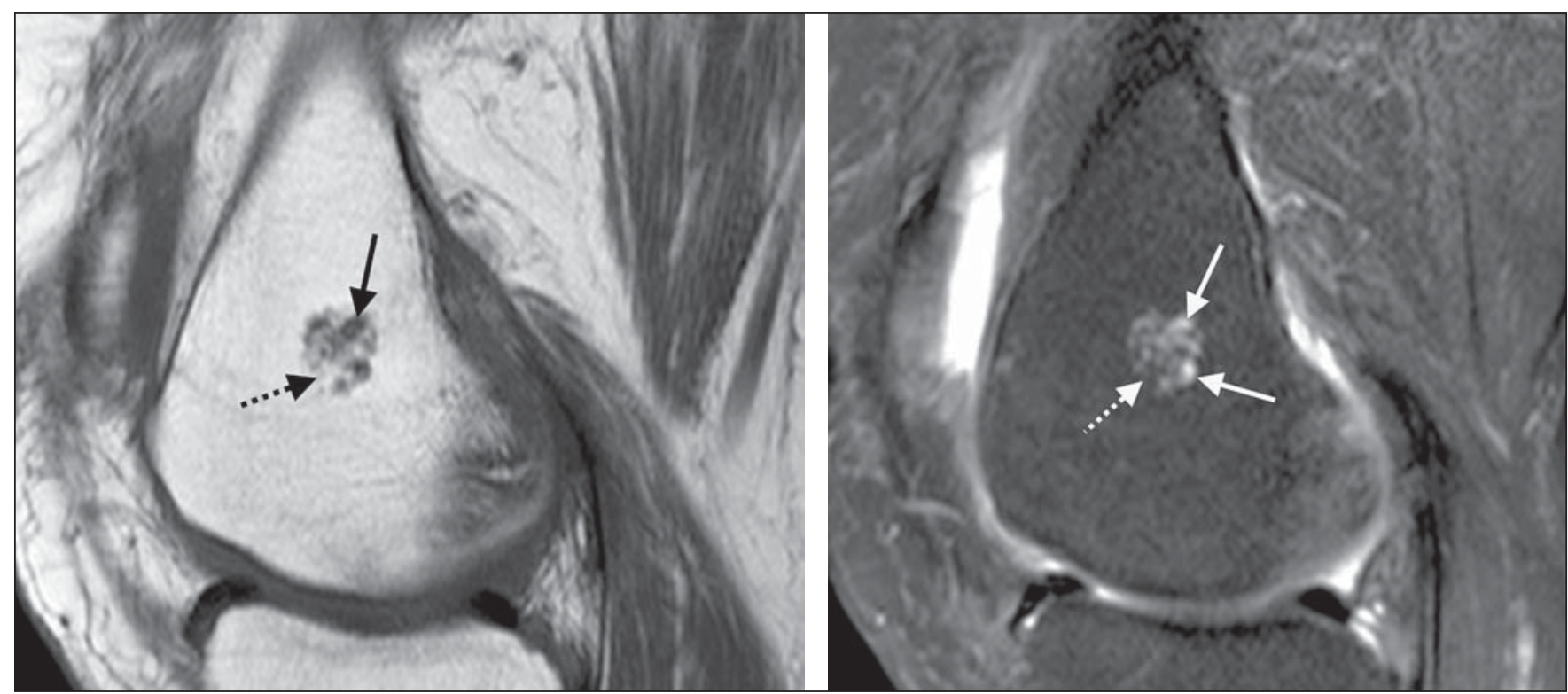

Figure 1. Female, 64-year-old patient. Magnetic resonance imaging demonstrating typical incidentally found enchondroma. A: On the sagittal T1-weighted image, the lesion presents foci of intermediate signal intensity, some of them with a lobular aspect (arrow), intermingled with areas of bone marrow and fat-like signal (dashed arrow). B: On the intermediate-weighted image with fat suppression, the lesion presents foci of hypersignal with lobular aspect (arrows). Areas of hypersignal on T1-weighted images are confirmed as fat and present signal suppression (dashed arrow).

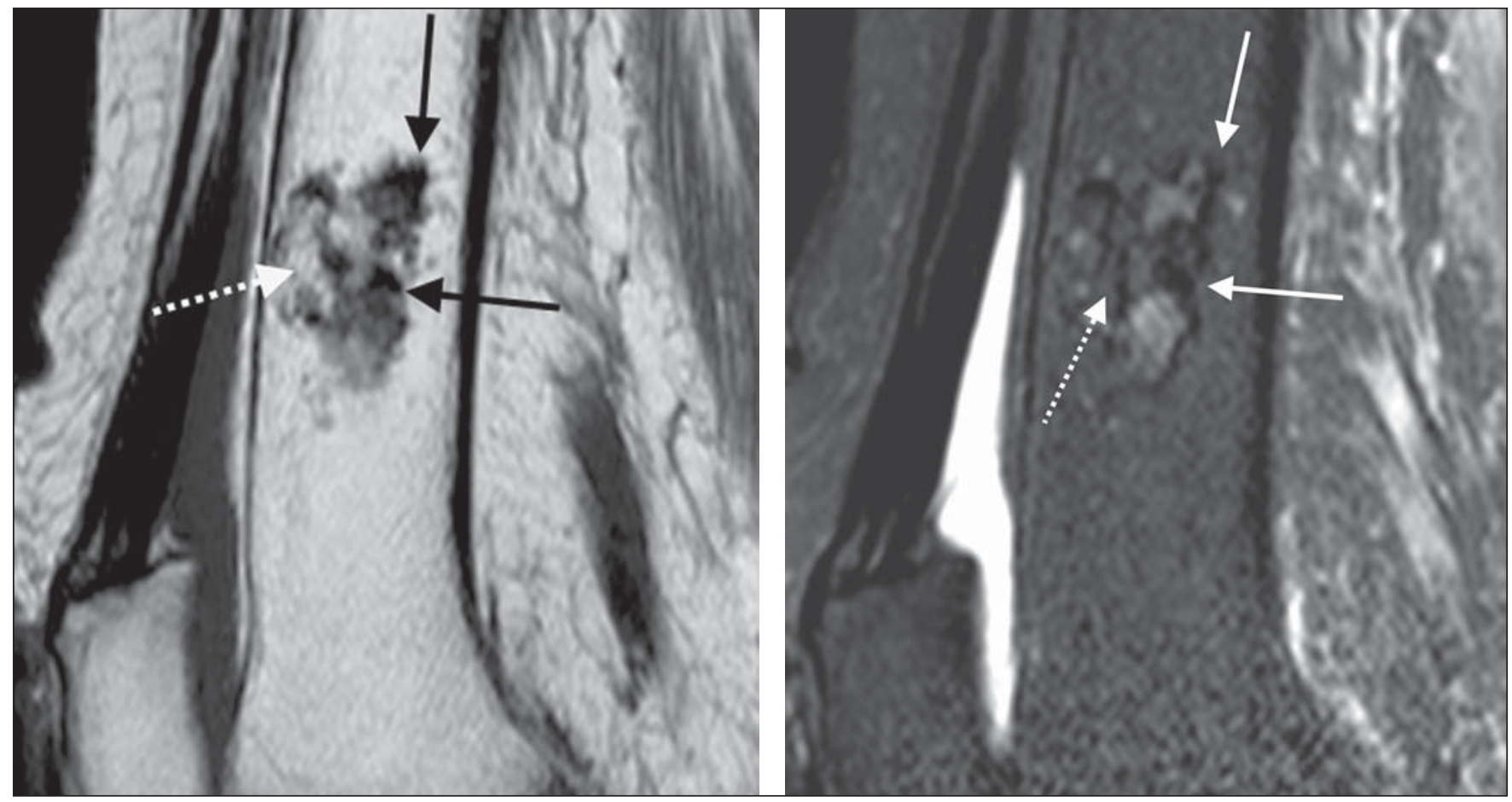

Figure 2. Female, 85-year-old patient. Magnetic resonance images demonstrate the presence of a typical incidentally found enchondroma. A: Sagittal T1weighted image. The black arrows indicate foci of signal absence. The dashed white arrow indicates a bone marrow area between cartilaginous lobules. B: Sagittal intermediate-weighted image with fat suppression. The arrows confirm the presence of foci of signal absence compatible with calcifications. The dashed arrow indicates an area of bone marrow between cartilaginous lobules.

$44.79 \%(n=146)], 56.13 \%(n=183)$ of the images depicted right knees, and $43.87 \%$ ( $n=143)$, left knees. The patients' ages ranged between 4 and 85 years (mean = 40.25 years) in the total sample, and be- tween 26 and 85 years ( mean $=46.5$ years) in the group of patients with enchondroma. Among the 11 enchondromas, six were found in male patients, five in the right knee. One patient presented two lesions in different bones (femur and tibia), detected on a single study.

Table 1 describes the characteristics of the 11 enchondromas found in the ten patients. Eight lesions were located in the 
Table 1 Cases of magnetic resonance imaging studies with focal alterations compatible with incidental enchondromas.

\begin{tabular}{|c|c|c|c|c|c|c|c|}
\hline Patient & $\begin{array}{c}\text { Age } \\
\text { (years) }\end{array}$ & Sex & Side & Location & $\begin{array}{l}\text { Largest diameter } \\
\qquad(\mathrm{cm})\end{array}$ & $\begin{array}{l}\text { Area with signal similar } \\
\text { to bone marrow }\end{array}$ & $\begin{array}{l}\text { Foci compatible } \\
\text { with calcification }\end{array}$ \\
\hline 1 & 64 & $\mathrm{~F}$ & $\mathrm{~L}$ & Distal femoral metaphysis & 2.2 & Yes & No \\
\hline 2 & 42 & M & $\mathrm{R}$ & Fibular head & 1.2 & Yes & No \\
\hline 3 & 35 & $\mathrm{~F}$ & L & Distal third of femoral diaphysis & 2.1 & No & Yes \\
\hline 4 & 26 & M & $\mathrm{R}$ & $\begin{array}{l}\text { Distal third of femoral diaphysis and proxi- } \\
\text { mal third of the tibia (two focal changes) }\end{array}$ & 1.0 and 1.2 & Yes and yes & Yes and yes \\
\hline 5 & 85 & $\mathrm{~F}$ & $\mathrm{R}$ & Distal third of femoral diaphysis & 3.2 & Yes & Yes \\
\hline 6 & 33 & $\mathrm{~F}$ & $\mathrm{~L}$ & Distal femoral metaphysis & 0.5 & No & No \\
\hline 7 & 44 & M & L & Distal third of femoral diaphysis & 1.4 & No & No \\
\hline 8 & 34 & M & $\mathrm{R}$ & Distal third of femoral diaphysis & 0.5 & No & No \\
\hline 9 & 43 & M & L & Proximal third of the tibia & 0.9 & No & Yes \\
\hline 10 & 57 & M & L & Distal third of femoral diaphysis & 0.5 & Yes & No \\
\hline
\end{tabular}

F, female; M, male; L, left; R, right.

distal femur, two in the proximal tibia, and one in the fibular head. The lesions dimensions ranged from 0.5 to $3.2 \mathrm{~cm}$ (mean = $1.34 \mathrm{~cm}$ ). Seven lesions were $\geq 1 \mathrm{~cm}$.

As regards presence of calcification signal within the enchondromas, intra and interobserver agreements were of $100 \%$ and, as regards fat signal within the lesion, indicating the presence of foci of bone marrow, the interobserver agreement was of $82 \%$, and the intraobserver agreement, $100 \%$.

In the whole sample of knee MRI studies, 22 lesions of other nature were found, as follows: osteochondromas $(n=5$; $1.53 \%)$; bone infarction $(n=3 ; 0.92 \%)$; osteosarcomas $(n=3 ; 0.92 \%)$; fibrocystic changes $(n=1 ; 0.30 \%)$, multiple subchondral cystic lesions in a patient with chronic hemarthropathy $(n=1 ; 0.30 \%)$, multiple lesions of paracoccidioidomycosis $(n=1$; $0.30 \%)$, intramedullary fibrous lesion $(n=$ 1 ; $0.30 \%)$, aneurysmal bone cyst ( $n=1$; $0.30 \%)$, chondrosarcoma ( $n=1 ; 0.30 \%)$, fibrous cortical defect/cortical desmoid ( $n$ $=1 ; 0.30 \%)$, lesion suspicious for metastasis $(n=1 ; 0.30 \%)$, pigmented villonodular synovitis $(n=1 ; 0.30 \%)$ and synovial sarcoma $(n=1 ; 0.30 \%)$.

\section{DISCUSSION}

The histopathological identification of foci of bone tissue or bone marrow within enchondromas has previously been described in the literature ${ }^{(\mathbf{1 5 - 1 7})}$. Cartilage lobules may be separated by normal bone marrow, or may be partially encased by mature lamellar bone ${ }^{(\mathbf{1 6})}$. This last characteristic is thought to reflect endochondral ossification in the periphery of the cartilage lobule ${ }^{(\mathbf{1 6})}$.

The differentiation between low-grade chondrosarcomas and enchondromas represents a challenge to radiologists, orthopedists and pathologists, since the treatment for each of these conditions is quite different, and their clinical, radiological and histopathological characteristics are very similar to each other ${ }^{(\mathbf{2 0 - 2 3})}$. The presence of bone tissue within the histopathologically identified lesion is potentially useful to differentiate enchondromas from low-grade intramedullary chondrosarcomas $^{(15,16,23)}$, but the applicability of such a concept in cases of MRI is still to be determined. In fact, the presence of foci of high signal intensity on MRI T1-weighted sequences, suggesting the presence of bone marrow within cartilaginous lesions, has not shown to be useful to differentiate such histological lesion types in at least two previous studies $^{(\mathbf{1 7}, 24)}$. The coexistence of both histological types in a single lesion could explain the identification of foci of bone marrow signal also in chondrosarcomas. Another hypothesis is that adjacent areas of healthy bone might have been invaded or involved by a low-grade chondrosarcoma. At MRI T1-weighted sequences, small foci of high signal intensity may be present in enchondromas as a result of the presence of engulfed normal medullary fat ${ }^{(25)}$.

According to Walden et al., the prevalence of incidentally found enchondromas at knee MRI was of $2.9 \%$, most of times lo- cated in the distal femur $(2.0 \%)^{(\mathbf{1 3})}$. In the study of Walden et al., the prevalence of lesions in the distal tibia corresponded to $0.7 \%$, and $0.2 \%$ in the fibula. The prevalence of incidentally found enchondromas in the present study $(3.3 \%)$ was, therefore, compatible with data in the literature. In the present study, the prevalence of enchondromas in the distal femur (2.4\%) was slightly higher than the prevalence observed by Walden et al ${ }^{(\mathbf{1 3})}$. Enchondromas may also be incidentally found with a relative frequency at routine shoulder studies $(2.1 \%)$, in most of times located in the contiguous region of the physis ${ }^{(\mathbf{2 6})}$. In that study ${ }^{(\mathbf{2 6})}$, the finding of areas of bone marrow within the lesion or intermingled with cartilage has not been investigated.

As compared with the prevalence of neoplasms such as chondrosarcomas and osteosarcomas in the general population, the high prevalence of such tumors in the present series is due to the fact that the authors' institution is a reference center for bone tumors.

The interobserver agreement in the classification of incidental enchondromas according to the criteria developed by Walden et al. was high, with a coefficient $\kappa$ of 0.84 [confidence interval (CI) 95\%: 0.65-1.00] in the first reading, and 1.00 (CI 95\%: $1.00-1.00)$ in the second reading performed three months after the first one. No other study evaluating this reproducibility is found in the literature.

The prevalence of foci of fat or bone marrow within enchondromas was of $54.55 \%$ ( 6 of 11 lesions). The intraobserver 
agreement for this finding was perfect, with $\kappa=1.00$ (CI 95\%: 1.00-1.00), and the interobserver agreement was $\kappa=0.82(\mathrm{CI}$ 95\%: 0.48-1.00).

The prevalence of calcifications within enchondromas was of $36.36 \%$ (4 of 11 lesions). Both intra- and interobserver agreements in relation to the finding of foci of calcification within enchondromas according to the criterion of low signal intensity at MRI were perfect, with $\kappa=1.00$ (CI 95\%: $1.00-1.00)$.

No significant relationship was observed between lesion size, patient's sex/ age and presence of foci of bone marrow within enchondromas, likewise for calcifications represented by foci of signal absence at MRI.

The present study has identified a high prevalence of foci of fat and calcification within enchondromas at MRI, and good reproducibility of such findings. The finding of areas with bone marrow signal intermingled with typically cartilaginous regions presented a higher prevalence than the finding suggestive of calcifications.

Some limitations of the present study must be mentioned. One of them - and important - is its retrospective nature. Other significant limitation is related to the fact that there was no histopathological evidence of the enchondromas, but the authors believe that such a limitation does not compromise the present study results, since the enchondromas were classified according criteria habitually accepted as reliable to characterize such lesions at MRI ${ }^{(13,17,26)}$.

\section{CONCLUSION}

The prevalence of incidentally found enchondromas in the present study $(3.3 \%)$ is compatible with data in the literature. In the present sample, the authors have ob- served a high prevalence of foci of fat and calcification within the lesions at MRI, and excellent agreement in the evaluation of these findings reproducibility. The finding of areas with bone marrow signal intermingled with typically cartilaginous regions had a higher prevalence than the finding suggestive of calcifications.

\section{REFERENCES}

1. Nogueira-Barbosa MH, Sá JL, Trad CS, et al. Ressonância magnética na avaliação das reações periosteais. Radiol Bras. 2010;43:266-71.

2. Ribeiro DS, Araújo Neto C, D'Almeida F, et al. Achados de imagem das alterações musculoesqueléticas associadas ao lúpus eritematoso sistêmico. Radiol Bras. 2011;44:52-8.

3. Simão MN, Nogueira-Barbosa MH. Ressonância magnética na avaliação das variações anatômicas meniscais e da anatomia ligamentar parameniscal: potenciais causas de erro de interpretação. Radiol Bras. 2011;44:117-22.

4. Tavares Júnior WC, Faria FM, Figueiredo R, et al. Fadiga óssea: causa de dor em joelhos na osteoartrite. Radiol Bras. 2012;45:273-8.

5. Nunes RB, Amaral DT, Oliveira VS. Propedêutica radiológica do impacto femoroacetabular em tempos de tomografia computadorizada e ressonância magnética: o que o radiologista precisa saber. Radiol Bras. 2011;44:249-55.

6. Grassi CG, Diniz FV, Garcia MRT, et al. Aspectos de imagem na tendinite calcária pré-vertebral. Radiol Bras. 2011;44:327-30.

7. Moura MVT. Interposição de fragmento periosteal na fratura da placa epifisária femoral distal: estudo por ressonância magnética. Radiol Bras 2012;45:184-6.

8. Nogueira-Barbosa MH, Savarese LG, Herrero CFPS, et al. Raízes nervosas redundantes da cauda equina: revisão da literatura. Radiol Bras. 2012;45:155-9.

9. Simão MN, Helms CA, Richardson WJ. Achados de ressonância magnética em cistos epidurais de origem discal em pacientes não operados e após microdiscectomia. Radiol Bras. 2012;45:205-9.

10. Jacob Jr C, Barbosa DM, Batista PR, et al. Fratura toracolombar do tipo explosão: o que o radiologista deve conhecer. Radiol Bras. 2012;45:101-4.

11. Chojniak R, Grigio HR, Bitencourt AGV, et al. Biópsia percutânea por agulha grossa de tumores de partes moles guiada por tomografia computadorizada: resultados e correlação com análise da peça cirúrgica. Radiol Bras. 2012;45:259-62.
12. Cotta AC, Melo RT, Castro RCR, et al. Dificuldades diagnósticas no osteoma osteoide do cotovelo: estudo clínico, radiológico e histopatológico. Radiol Bras. 2012;45:13-9.

13. Walden MJ, Murphey MD, Vidal JA. Incidental enchondromas of the knee. AJR Am J Roentgenol. 2008;190:1611-5.

14. Kaplan PA, Dussault R, Helms CA, et al. Musculoskeletal MRI. Philadelphia, PA: WB Saunders; 2001.

15. Mirra JM, Gold R, Downs J, et al. A new histologic approach to the differentiation of enchondroma and chondrosarcoma of the bones. A clinicopathologic analysis of 51 cases. Clin Orthop Relat Res. 1985;(201):214-37.

16. McCarthy EF, Tyler WK. Distinguishing enchondroma from low-grade central chondrosarcoma. Pathol Case Rev. 2001;6:8-13.

17. Murphey MD, Flemming DJ, Boyea SR, et al Enchondroma versus chodrosarcoma in appendicular skeleton: differentiating features. Radiographics. 1998;18:1213-37.

18. Agresti A. Categorical data analysis. New York, NY: John Wiley; 1990.

19. Landis JR, Koch GG. The measurement of observer agreement for categorical data. Biometrics. 1977;33:159-74.

20. Ferrer-Santacreu EM, Ortiz-Cruz EJ, GonzálezLópez JM, et al. Enchondroma versus low-grade chondrosarcoma in appendicular skeleton: clinical and radiological criteria. J Oncol. 2012;2012: 437958.

21. Shariat Torbaghan S, Ashouri M, Jalayer Naderi $\mathrm{N}$, et al. Histopathologic differentiation between enchondroma and well-differentiated chondrosarcoma: evaluating the efficacy of diagnostic histologic structures. J Dent Res Dent Clin Dent Prospects. 2011;5:98-101.

22. Donthineni R, Ofluoğlu O. Solitary enchondromas of long bones: pattern of referral and outcome. Acta Orthop Traumatol Turc. 2010;44: 397-402.

23. Vanel D, Kreshak J, Larousserie F, et al. Enchondroma vs. chondrosarcoma: a simple, easy-to-use, new magnetic resonance sign. Eur J Radiol. 2012 Jan 5. [Epub ahead of print].

24. Choi BB, Jee WH, Sunwoo HJ, et al. MR differentiation of low-grade chondrosarcoma from enchondroma. Clin Imaging. 2013;37:542-7.

25. Douis H, Saifuddin A. The imaging of cartilaginous bone tumours. I. Benign lesions. Skeletal Radiol. 2012;41:1195-212.

26. Hong ED, Carrino JA, Weber KL, et al. Prevalence of shoulder enchondromas on routine MR imaging. Clin Imaging. 2011;35:378-84. 